\title{
ASSESSMENT OF QUALITY OF LIFE OF PATIENTS AFTER SURGERY MADE BY THE IN-HOUSE DEVICES AND METHODS
}

10.36740/WLek202012119

\author{
Nataliia 0. Riabushko, Roman M. Riabushko, Mykola M. Riabushko, Olena B. Riabushko \\ UKRAINIAN MEDICAL STOMATOLOGICAL ACADEMY, POLTAVA, UKRAINE
}

\begin{abstract}
The aim: To estimate the patients' quality of life after surgery made by the in-house devices and methods.

Materials and methods: According to the peculiarities of surgical treatment, the set of instruments used and the methods of its application during surgery, all patients were assigned into two groups: group I (comparison group, or retrospective group) involved 48 (58.5\%) patients who received treatment at the Vascular Surgery Department and had contraindications to endovascular laser and radiofrequency ablation, as evidenced by ultrasonographic color angioscanning (USCAS). These patients underwent typical phlebectomies, which were performed using a standard set of instruments; group II (prospective) involved 34 (41.5\%) patients treated in the Surgery Department. Patients of this group also had contraindications to endovenous laser and radiofrequency ablation, which was confirmed by USCAS data.

Results: It has been found that following the six months after treatment, no patient in Group II and Group I measured the quality of life unsatisfactory. Satisfactory measures were made by 6 (12.5\%) and 2 (5.9\%) patients in Group I and Group II, respectively. Good scores of quality of life was established in 33 (68.75\%) and 19 (55.9\%) patients, respectively. Excellent scores were observed in patients of Group I ( 9 (18.75\%)) and Group II (13 (38.2\%)). In addition, in our survey, patients' responses were divided into three categories: "Never", "Rarely", "Quite often", "Very often", "Constantly". That is, with a negative outcome (incomplete disappearance of the symptom, its apparent reduction), we can observe the dynamics of positive changes.

Conclusions: Patients of Group II had a higher rates of quality of life, because the process of ulcer healing was faster, pain was reducing, contributing to improvement of the patient's psycho-emotional state. In addition, the examined 29 (85.3\%) patients of Group II noted that even with the preservation of some symptoms, their subjective manifestations were reducing leading to health improvement. All this contributes to improving the quality of life of patients with trophic ulcers of the lower extremities, which were treated according to our methods.
\end{abstract}

KEY WORDS: surgery, quality of life, in-house devices and methods

Wiad Lek. 2020;73(12 p. I):2664-2666

\section{INTRODUCTION}

Currently, the issues of determining the effectiveness of treatment of trophic venous ulcers and the phenomena of chronic venous insufficiency (CVI) studied incompletely to date. In this case, it is necessary to take into account not only the objective data, but also subjective opinion, i.e. how patients themselves evaluate the outcomes of treatment. Therefore, one of the methods of standardization of the study of CVI phenomena is the CEAP international classification, which is widely used in the scientific environment. However, it doesn't provide with objective assessment of the long-term outcomes of treatment $[1,2]$.

The study of the scientific publications has established that some authors suggest to form groups of patients that would be equivalent in clinical manifestations and to develop objective criteria for assessing the condition and severity of this pathology when analyzing methods of treatment of venous pathology of the lower extremities [3,4]. However, it is crucial to establish how the effectiveness of treatment of venous pathology of lower extremities, especially surgical one, impacts the quality of life (QOL) of patients in the long term period.
It is known that QOL is characterized by the physical, mental, social and emotional state of a person according to his or her subjective perception [5]. In addition, in this concept, some authors include subjective satisfaction from different aspects of human life, happiness and attitudes to the negative and positive moments of life [6]. And the WHO defines QOL as an individual state of a person in the society, attitude to culture, system of the values, goals of each individual, his or her plans, opportunities, general satisfaction and dissatisfaction [7].

\section{THE AIM}

The aim was to estimate the patients' quality of life after surgery made by the in-house devices and methods.

\section{MATERIALS AND METHODS}

According to the peculiarities of surgical treatment, the set of instruments used and the methods of its application during surgery, all patients were assigned into two groups: - Group I (comparison group, or retrospective group) involved 48 (58.5\%) patients who received treatment 
at the Vascular Surgery Department and had contraindications to endovascular laser and radiofrequency ablation, as evidenced by ultrasonographic color angioscanning (USCAS). These patients underwent typical phlebectomies, which were performed using a standard set of instruments;

- Group II (prospective) involved 34 (41.5\%) patients treated in the Surgery Department. Patients of this group also had contraindications to endovenous laser and radiofrequency ablation, which was confirmed by USCAS data. Surgical treatment involved surgical interventions, which were performed using devices developed by us: to dilute the wound edges, isolation and ligation of perforant veins and vena saphena magna, non-traumatic suturing of postoperative wounds [8-15]. All surgical interventions made for patients in this group were supplemented with ultrasound.

\section{RESULTS AND DISCUSSION}

Assessment of the patient's quality of life was studied using the questionnaire designed by us. The Chronic Venous Insufficiency Questionnaire (CIVIQ) scale was chosen as the basis for assessing the quality of life of patients with trophic ulcers of the lower extremities.

To assess the quality of life of the patient, the survey was conducted before surgery, and again 1 month, 3 months and six months after surgery. A comparative assessment of the dynamics of changes in the global post-operative quality of life depending on the features of the selected treatment was made.

The detailed analysis of the surveys completed by patients of Group I and Group II, has shown that most patients complained of pain in the legs ( $99 \%$ of patients), heaviness in the lower extremities (95\% of patients), edema ( $82 \%$ of patients), and cramps ( $68 \%$ of patients). In addition, all examined patients reported about poor psycho-emotional state, deterioration of social activity. This indicated that patients in Groups I and II had identical complaints and symptoms before treatment.

The patients were invited to complete the survey again 1 month, 3 months and six months after comprehensive treatment. During the survey, we made emphasis on the same parameters as before treatment. That is, upon calculation of the rates of quality of life of patients of both groups, we found that 59 patients $(72 \%)$ measured the quality of life unsatisfactory and 23 patients (28\%) assessed it satisfactory.

The resulting data have shown that such parameter as "pain sensation" in patients of the main group decreased with each follow-up survey, and after 6 months the pain sensation was not reported. In the comparison group, the "pain" parameter was also decreasing, but not as intensely.

Consequently, the intensity of pain in Group II patients following a month, 3 months and after six months decreased by $18 \%, 23 \%$ and $11 \%$, respectively. And in Group I patients it decreased by $13 \%, 19 \%$ and $9 \%$, respectively. This can be the result of both immediate and long-term outcomes of the surgery.
The mental component of the survey was also scored by patients of both groups. We hypothesize that the psycho-emotional state of the patient depends entirely on the physical condition of the patient.

In Group II, 16 (47\%) patients gave unsatisfactory assessment and 18 (53\%) satisfactory. Accordingly, in Group I unsatisfactory and satisfactory scores were given by 30 (62.5\%) and 18 (37.5\%) patients, respectively. The resulting data have shown no significant change in the quality of life of patients following one month after treatment, except for insignificant pain relief.

Similar follow-up survey was completed again after 3 months and the analysis of the resulting data has shown 5 $(10.4 \%)$ and $3(8.8 \%)$ patients with unsatisfactory assessment of quality of life in Group I and Group II, respectively and 17 (35.4\%) and $4(11.8 \%)$ patients with satisfactory assessment, respectively. A good assessment of quality of life was made by 21 (61.8) patients of Group II and 24 (50\%) patients of Group I. The quality of life was assessed as "excellent" by 6 (17.6) and 2 (4.2\%) patients of each group, respectively.

Thus, following 3 months after comprehensive treatment a positive dynamics in the quality of life of patients in Groups I and II was observed. Therefore, a follow-up survey was made after 6 months for a better assessment of the data. It has been found that following the six months after treatment, no patient in Group II and Group I measured the quality of life unsatisfactory. Satisfactory measures were made by $6(12.5 \%)$ and $2(5.9 \%)$ patients in Group I and Group II, respectively. Good scores of quality of life was established in 33 (68.75\%) and 19 (55.9\%) patients, respectively. Excellent scores were observed in patients of Group I $(9(18.75 \%))$ and Group II (13 (38.2\%)). In addition, in our survey, patients' responses were divided into three categories: "Never", "Rarely", "Quite often", "Very often", "Constantly". That is, with a negative outcome (incomplete disappearance of the symptom, its apparent reduction), we can observe the dynamics of positive changes..

\section{CONCLUSIONS}

Patients of Group II had a higher rates of quality of life, because the process of ulcer healing was faster, pain was reducing, contributing to improvement of the patient's psycho-emotional state. In addition, the examined 29 (85.3\%) patients of Group II reported that even with the preservation of some symptoms, their subjective manifestations were reducing leading to health improvement. All this contributes to improving the quality of life of patients with trophic ulcers of the lower extremities, which were treated according to our methods.

\section{REFERENCES}

1. Shybelgut N., zakharov l., Mozas V. Kolesnikova N. Kaczestvo zhyzni u zhenshchin s barikoznoj bolezniu ven malogo taza. Angiologia i sosudistaia chirurgia. 2010;16(2):50-3.

2. Komarova L., Riachin R., Alijev F., Zvezda S. Rezultaty lechenia bolnykh varikoznoj bolezniu nizhnikh konechnostiej za 10 let. Arkhiv vnutrenniej medicyny. 2018;8(3 (41)). 
3. Mosti G, Partsch H. Compression stockings with a negative pressure gradient have a more pronounced effect on venous pumping function than graduated elastic compression stockings. European Journal of Vascular and Endovascular Surgery. 2011;42(2):261-6.

4. Siribumrungwong B, Noorit P, Wilasrusmee C, Attia J, Thakkinstian A. A systematic review and meta-analysis of randomised controlled trials comparing endovenous ablation and surgical intervention in patients with varicose vein. European journal of vascular and endovascular surgery. 2012;44(2):214-23.

5. Biemans A, van derVelden SK, Bruijninckx C, Buth J, Nijsten T. Validation of the chronic venous insufficiency quality of life questionnaire in Dutch patients treated for varicose veins. European Journal of Vascular and Endovascular Surgery. 2011;42(2):246-53.

6. zhukov B.N., Katorkin S.E., Zhukov A.A., Puti povyshenija efektivnosti kompleksnogo lechenija pacyentov $s$ chronicheskimi zabolevanijami ven C6 klinicheskogo klassa. Vestnik medicynskogo nstityta „REVIZ”: reabilitacyja, vrach i zdorovie. 2015 (2 (18)).

7. Wittens $\mathrm{CH}$, Bukkems SF, Toonder IT. Abdominal Wall Venous Collaterals. Circulation. 2010;122:2089-90.

8. Liakhovkyi V.I., Bobyriov V.M., Riabushko R.M., Riabushko M.M. vynakhidnyk; Ukrainska medychna stomatologichna akademia, patentovlasnyk. Sposib rozvedenia kraiv rany pry pereviazci perforantnykh ven u khvorykh na trofichni vyrazky nyzhnikh kincivok venoznogo genezu. Patent Ukrainy №104038. 2016 Sich 12.

9. Liakhovskyi V.I., Riabushko R.M. Sakevych R.P., Riabushko O.B., to in. vynakhidnyk; Ukrainska medychna stomatologichna akademia, patentovlasnyk. Sposib formuvannia kuksy velykoi pidshkirnoi veny pry krosektomii u khvorykh na trofichni vyrazky venoznoi etiologii nyzhnikh kincivok. Patent Ukrainy №110411. 2016 Zhov 10.

10. Liakhovskyi V.I., Demianiuk D.G., Riabushko R.M. ta in. vynakhidnyk; Ukrainska medychna stomatologichna akademia, patentovlasnyk. Prystrij dlia rozvedenia kraiv ta ushvannia rany pry formuvanni estetychnogo rubcia. Patent Ukrainy №88287. 2014 Ber 11.

11. Liakhovskyi V.I., Demianiuk D.G., Riabushko R.M. ta in. vynakhidnyk; Ukrainska medychna stomatologichna akademia, patentovlasnyk. Prystrij dlia rozvedenia kraiv ta ushvannia ran. Patent Ukrainy №88938. 2014 Kvit 10.

12. Liakhovskyi V.I., Demianiuk D.G., Riabushko R.M. ta in. vynakhidnyk; Ukrainska medychna stomatologichna akademia, patentovlasnyk. Prystrij dlia formuvannia kuksy velykoi pidshkirnoi veny. Patent Ukrainy №89090. 2014 Kvit 10.
13. Khimich S.D., Liakhovskyi V.I., Demianiuk D.G., Riabushko R.M. vynakhidnyk; Ukrainska medychna stomatologichna akademia, patentovlasnyk. Prystrij dlia rozvedenia kraiv ta ushvannia kraiv ran pry venektomii. Patent Ukrainy №89091. 2014 Kvit 10.

14. Zhdan V.M., Liakhovskyi V.I., Riabushko R.M. vynakhidnyk; Ukrainska medychna stomatologichna akademia, patentovlasnyk. Prystrij dlia rozvedenia kraiv ta ushvannia rany pry flebektomijakh ta inshych miniinvazywnykh vtruchanniakh. Patent Ukrainy №90839.2014 Cher 10.

15. Zhdan V.M., Liakhovskyi V.I., Riabushko R.M. vynakhidnyk; Ukrainska medychna stomatologichna akademia, patentovlasnyk. Prystrij dlia rozvedenia kraiv ta ushvannia rany pry pereviazci perforantnykh ven. Patent Ukrainy №91590. 2014 Lyp 10.

\section{ORCID and contributionship:}

Nataliia O. Riabushko: 0000-0002-3699-0291 A,E,F

Roman M. Riabushko: 0000-0002-5073-9095 B,D,C

Mykola M. Riabushko: 0000-0002-3617-4542 E,F

Olena B. Riabushko: 0000-0003-0249-4852 B,D,F

\section{Conflict of interest:}

The Authors declare no conflict of interest

\author{
CORRESPONDING AUTHOR \\ Olena B. Riabushko \\ Department of Medical Biology \\ Ukrainian Medical Stomatological Academy, \\ Shevchenko 23 str., 36011, Poltava, Ukraine \\ tel: +380668345147 \\ e-mail: ryabushko12@ukr.net
}

Received: 20.05 .2020

Accepted:27.10.2020

A - Work concept and design, B - Data collection and analysis, C - Responsibility for statistical analysis, D-Writing the article, $\mathbf{E}$ - Critical review, $\mathbf{F}$ - Final approval of the article 